\title{
Effect of Acid Contamination on the Geotechnical Properties of Cohesive Soils from Oke-Ejigbo area of Abeokuta, South-western Nigeria
}

\section{*11ADEKUNLE, AA; ${ }^{2}$ OMOBOLAJI, O; ${ }^{3}$ ISAAC, UI; ${ }^{1}$ AKINBAMI, AT}

\author{
${ }^{* 1}$ Department of Civil Engineering, Federal University of Agriculture, Abeokuta, Nigeria. \\ ${ }^{2}$ Department of Civil Engineering, Olabisi Onabanjo University, P.M.B 5026, Ibogun Campus, Ifo, Ogun State, Nigeria \\ ${ }^{3}$ Department of Chemistry, Federal University Otuoke. Bayelsa State, Nigeria. \\ "Corresponding Author Email: adebolamay@gmail.com; Tel.: +2348033010552
}

\begin{abstract}
Environmental degradation is a threat to the ecosystem and natural resources. The research investigated the effects of hydrochloric acid contamination on the geotechnical properties of cohesive soils obtained from Oke-Ejigbo area of Abeokuta, South-western Nigeria. The materials used are hydrochloric acid as contaminant, red clay (RCA) and white clay (WCA) soils respectively. The results of optimum moisture content, maximum dry densities, California bearing ratio and unconfined compressive strength of RCA and WCA subjected to 60 days acidic contamination period are (14.88 and $16.21 \%),\left(18.30\right.$ and $\left.17.93 \mathrm{kN} / \mathrm{m}^{3}\right),(5.93$ and $11.29 \%),\left(89.81\right.$ and $\left.87.54 \mathrm{kN} / \mathrm{m}^{3}\right)$ respectively. The acid-soil interaction reduces the geotechnical properties of the cohesive soil samples with an increase in the period of contamination. Furthermore, the contamination period directly affects the strength of the soils due to the change in soil plasticity and structure caused by the pollutant
\end{abstract}

DOI: https://dx.doi.org/10.4314/jasem.v25i6.9

Copyright: Copyright $\odot 2021$ Adekunle et al. This is an open access article distributed under the Creative Commons Attribution License (CCL), which permits unrestricted use, distribution, and reproduction in any medium, provided the original work is properly cited.

Dates: Received: 20 March 2021; Revised: 27 April 2021; Accepted: 07 May 2021

Keywords: Acidic contamination, cohesive soils, geotechnical properties, pollution

Environmental pollution is a threat to human survival. One of the primary factors of environmental degradation in a region could be attributed to industrialization and mode of waste management technique adopted, which adversely affects the ecosystem and natural resources. The effect of pollutants can be very similar to the effect of weathering. The nature of soil pollutant interactions depends on the mineralogy of soil and type and concentration of the pollutant (Umesha, et al., 2012). Prakash and Arumairaj (2015) classified substances such as inorganic acids, alkalis, sulphates, organic contaminants, toxic or phytotoxic metals and combustible substances as the major soil contaminants. Ratnaweera and Meegoda (2006) investigated the effect of organic fluids on the stressstrain behaviour of soil. They observed that the dielectric constant of the organic fluids directly affects the changes in the strength of the soil. Rahman et al., (2010) studied the effects of artificial oil contamination on the geotechnical properties of soil. A reduction in permeability was observed as a result of oil contamination. The plastic and liquid limits significantly decreased by $19-39 \%$. The undrained shear strength, cu was $126 \mathrm{kPa}$ for natural soil had dropped to very close values of $35 \mathrm{kPa}$ at oil content of $16 \%$. Irfan et al., (2018) evaluated the effects of acidic and basic industrial effluents on geotechnical characteristics of cohesive soils. They observed that the geotechnical characteristics of the cohesive soils deteriorated upon effluent contamination thereby causing potential risks to future, as well as existing, construction at such sites. Gratchev and Towhata (2009) studied the consequence of acidic contamination on the geotechnical characteristics of some selected soils from coastal areas in Japan. They concluded that long-term soil-acid interaction acidic could influence the compressibility properties of the clays, and the degree of changes is dependent on their mineralogy, soil structure, and the duration of soil-acid interaction. Pollution of soil directly affects the mechanics of soil due to changes in the geotechnical behaviour of foundation soil. It is imperative to study the influence of pollutants on soil properties to forestall various geotechnical problems. This research tends to investigate the effect of acid contamination on the geotechnical properties of cohesive soils obtained from Oke-Ejigbo area of Abeokuta, South-western Nigeria.

\section{MATERIALS AND METHODS}

Sampling: Red clay sample: This material was collected from the road along with COLANIM farm at the Federal University of Agriculture, Abeokuta 
within the geographical coordinates of latitude $7.227^{\circ}$ $\mathrm{N}$ and longitude $3.43^{\circ} \mathrm{E}$. It is designated as RCA (Red clay soil). The soil has a liquid limit, plastic limit and plastic index of $49.15,41.03$ and $8.12 \%$ respectively. The soil possesses specific gravity, natural moisture content, compressive strength and CBR values of 2.49 , $11.29 \%, 135.34 \mathrm{kN} / \mathrm{m}^{2}$ and $9.51 \%$ respectively.

White clay sample: This material was sourced from Oke-Ejigbo area of Abeokuta, both towns in the Southwestern part of Nigeria within the geographical coordinates of latitude $7.202^{\circ} \mathrm{N}$ and longitude $3.442^{\circ}$ E. It is designated as WCA (White clay soil). The soil has a liquid limit, plastic limit and plastic index of $41.3,30.7$ and $10.6 \%$ respectively. The soil possesses specific gravity, natural moisture content, compressive strength and CBR values of $2.00,34.52 \%, 111.69$ $\mathrm{kN} / \mathrm{m}^{2}$ and $21.78 \%$ respectively.

Sample preparation: The soil samples were air-dried at room temperature $\left(25-28^{\circ} \mathrm{C}\right)$ for a week, employing measures that would avoid contamination. The dried samples were manually pulverized and stored in labelled plastic bags for testing. Each test was duplicated to ensure the reliability of results. Distilled water and prepared solutions of hydrochloric acid of pH 7.1 and 3.0 respectively were used for this research. The red and white clay soils were soaked in acid and distilled water for a period of 60 days. The influences of acidic contamination on the index and geotechnical characteristics of the soils were assessed at a 30 days interval.

Evaluation of Geotechnical Properties in the Acid Contaminated Soils: Determination of specific gravity: The specific gravity $\left(\mathrm{G}_{\mathrm{s}}\right)$ was carried out with the aid of pycnometer bottles, thermometer, funnel and weighing balance. The $\mathrm{G}_{\mathrm{s}}$ of the RCA and WCA was determined in accordance was determined according to BS 1377-part II (1990) by using the pycnometer method.

Determination of Atterberg limits: The acidic contaminated RCA and WCA soil samples were oven dried and sieved through the $0.4 \mathrm{~mm}$ (425 microns) sieve. A substantial amount was mixed and placed at the centre of the Casagrande's liquid limit device cup and spread out evenly, after which a groove was made by the grooving tool. The cup was dropped from a height of $10 \mathrm{~mm}$ at the rate of 2 revolutions per second till the two halves of soil came in contact for a distance of $13 \mathrm{~mm}$. Thereafter, the moisture content was analysed to determine their respective liquid limits. The Plastic Limits was analysed by determining the water content at which the prepared soil samples would deform by rolling into approximately $3 \mathrm{~mm}$ diameter threads without crumbling.

Determination of Compaction Characteristics: This test was carried out to ascertain the relationship between the moisture content and the dry density of the soil samples with the aid of a standard Proctor's 101.6 $\mathrm{mm}$ mould and $2.5 \mathrm{~kg}$ rammer. The light compaction tests were performed in accordance with procedures outlined in BS 1377:part 4 (1990).

Determination of California bearing ratio: The California Bearing Ratio test was carried out on the compacted RCA and WCA samples in the laboratory. A plunger of standard area was used to penetrate the samples in the soaked condition according to the procedures outlined in BS 1377-part 7: (1990).

Determination of strength characteristics: The strength characteristics of the acidic contaminated RCA and WCA soil samples were assessed using the unconfined compressive test specimens of $90 \mathrm{~mm}$ height and $45 \mathrm{~mm}$ diameter according to the procedures outlined in BS 1377-part 7:(1990).

\section{RESULTS AND DISCUSSION}

Influence of contamination on specific gravity: The influence of acidic contamination on the specific gravity of the soil specimens are presented in Table 1 . The average values for the specific gravity of red clay and white clay in their natural states at $28^{\circ} \mathrm{C}$ are 2.49 and 2.00 respectively. Specific gravity values of 2.73 and 2.42 were obtained for red and white clay soils respectively when soaked in acid during the initial 30 days. The specific gravity value of red and white clay increased to 2.84 and 2.63 respectively at the end 60 days of acidic contamination. This phenomenon is due to the low density of the contaminant applied.

Table 1: Specific gravity of the soil samples

\begin{tabular}{lll}
\hline Days & RCA & WCA \\
\hline 0 & 2.49 & 2.00 \\
30 & 2.73 & 2.42 \\
60 & 2.84 & 2.63
\end{tabular}

$R C A$ and WCA are red clay and white clay soaked in acid respectively

Effects on Atterberg limits: The result of the Atterberg limits analysis is presented in Table 2 . The liquid limit of red and white clay soils in their natural states are $49.15 \%$ and $41.30 \%$ respectively. According to Unified Soil Classification System (USCS), red and while clay soils are classified as inorganic silts with slight plasticity (ML) respectively. The Atterberg limits of the soil samples decreased with an increase of contamination period (Table 2). 
Effects on compaction characteristics: The summary of compaction test results is shown in Table 3. The natural Optimum Moisture Contents (OMC) and Maximum Dry Densities (MDD) for red and white clay soils are $16.4 \%$ and $17.96 \mathrm{kN} / \mathrm{m}^{3}, 17.6 \%$ and $16.21 \mathrm{kN} / \mathrm{m}^{3}$ respectively. The MDD of white clay increases with increase in the age of contamination while that of red clay decreased with an increase in the number of days (Table 3). The OMC of the two soils decreases with an increasing number of days. Similar trends were observed by Pandian et al., (1997) and Sridharan et al. (2005). The increase in MDD and decrease in OMC of the soil samples could be attributed to the change in soil plasticity caused by the period of contamination.

Table 2: Atterberg limits of the soil samples

\begin{tabular}{llllllllll}
\multicolumn{10}{c}{ Table 2: Atterberg limits of the soil samples } \\
\hline \multirow{3}{*}{ Samples } & Liquid limit $(\%)$ & \multicolumn{4}{c}{ Plastic limit $(\%)$} & \multicolumn{4}{c}{ Plasticity index (\%) } \\
\cline { 2 - 10 } & 0 & 30 & 60 & 0 & 30 & 60 & 0 & 30 & 60 \\
& (day) & (days) & (days) & (day) & (days) & (days) & (day) & (days) & (days) \\
\hline RCA & 49.15 & 41.01 & 37.51 & 41.03 & 28.47 & 28.02 & 8.12 & 12.54 & 9.49 \\
WCA & 44.60 & 41.30 & 34.14 & 30.70 & 31.43 & 28.18 & 13.90 & 9.87 & 5.96 \\
\hline
\end{tabular}

Table 3: Compaction characteristics of the soil samples

\begin{tabular}{lllllll}
\hline \multirow{3}{*}{ Parameters } & 0 (day) & \multicolumn{3}{c}{30 (days) } & \multicolumn{3}{c}{60 (days) } \\
\cline { 2 - 7 } & $\begin{array}{l}\text { MDD } \\
\left(\mathrm{kN} / \mathrm{m}^{3}\right)\end{array}$ & $\begin{array}{l}\text { OMC } \\
(\%)\end{array}$ & $\begin{array}{l}\text { MDD } \\
\left(\mathrm{kN} / \mathrm{m}^{3}\right)\end{array}$ & $\begin{array}{l}\text { OMC } \\
(\%)\end{array}$ & $\begin{array}{l}\text { MDD } \\
\left(\mathrm{kN} / \mathrm{m}^{3}\right)\end{array}$ & $\begin{array}{l}\text { OMC } \\
(\%)\end{array}$ \\
\hline RCA & 17.96 & 16.4 & 18.65 & 16.44 & 18.3 & 14.88 \\
WCA & 17.9 & 17.6 & 17.76 & 16.43 & 17.93 & 16.21 \\
\hline
\end{tabular}

$R C A$ and WCA are red clay and white clay soaked in acid respectively. MDD = Maximum Dry Density, OMC = Optimum Moisture Content

Effects of contamination on California Bearing Ratio: The result of the California Bearing Ratio (CBR) is presented in Table 4. The CBR values for red clay and white clay soils prior to acidic contamination are $9.15 \%$ and $21.78 \%$ respectively. Figure 6 shows the trends observed when different soils were soaked in acid at varying age. With an increase in the age of concentration, the CBR values for red clay and white clay slightly decreased from $6.48 \%$ to $5.93 \%$ and $12.63 \%$ to $11.29 \%$ respectively (Table 4 ).

Table 4: California Bearing Ratio (CBR) characteristics of the soil

\begin{tabular}{llll}
\multicolumn{5}{c}{ samples } \\
\hline Parameters & 0 (day) & 30 (days) & 60 (days) \\
\hline RCA $(\%)$ & 9.15 & 6.48 & 5.93 \\
WCA $(\%)$ & 21.78 & 12.63 & 11.29 \\
\hline RCA and WCA are red clay and white clay soaked in acid \\
respectively.
\end{tabular}

Effects of contamination on strength characteristics: The results of the Unconfined Compressive Strength (UCS) are shown in Table 5. The UCS values for red clay and white clay soils prior to acidic contamination are 135.34 and $111.69 \mathrm{kN} / \mathrm{m}^{3}$ respectively. The strength of red and white clay soils slightly decreased by $77.2 \%$ and $80.4 \%$ respectively at the end of initial 30 days contamination period while a sharp decrease of $66.4 \%$ and $78.4 \%$ was observed in red and white clay soil respectively at the end of 60 days acidic contamination period.

Conclusion: The analysis of acid-soil interaction resulted to the general decrease of the index and geotechnical properties of red and white clay soils.
Furthermore, the period of contamination directly affects the strength of the soils due to change in soil plasticity and structure caused by the pollutant. However, the geo-environmental impact on contaminated soils could be mitigated through the application of various remediation techniques.

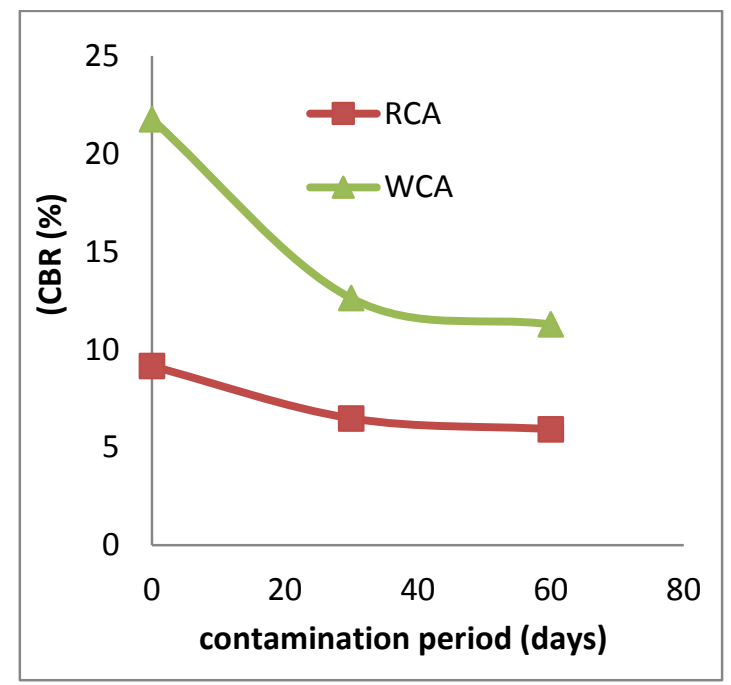

Fig 6: Effects of acidic contamination on CBR properties

Table 5: Unconfined compressive strength of the soil samples

\begin{tabular}{llll}
\hline Parameters & 0 (day) & 30 (days) & 60 (days) \\
\hline RCA $\left(\mathrm{kN} / \mathrm{m}^{3}\right)$ & 135.34 & 104.44 & 89.81 \\
WCA $\left(\mathrm{kN} / \mathrm{m}^{3}\right)$ & 111.69 & 89.75 & 87.54
\end{tabular}

WCA $\left(\mathrm{kN} / \mathrm{m}^{3}\right) \quad 111.69 \quad 89.75 \quad 87.54$

$R C \overline{A \text { and } W C A \text { are red and white clay soaked in acid respectively. }}$ 


\section{REFERENCES}

BS 1377 (1990). Methods of Tests for soils for Civil Engineering Purposes. British Standards Institutions, London.

Gratchev, IB; Towhata, I (2009). Effects of Acidic Contamination on the Geotechnical Properties of Marine Soils in Japan. Proceedings of the Nineteenth (2009) International Offshore and Polar Engineering Conference Osaka, Japan, June 21-26, 2009: $151-155$

Irfan, M; Chen, Y; Ali, M; Abrar, M; Qadri, A; Bhutta, O (2018). Geotechnical Properties of EffluentContaminated Cohesive Soils and Their Stabilization Using Industrial ByProducts. Processes. 6, 203

Pandian, N; Nagaraj, T; Manoj, M (1997). Reexamination of compaction characteristics of finegrained soils. Geotechnique. 47; 363-366.
Prakash, S; Arumairaj, PD (2015). Effects of Acid and Base Contamination on Geotechnical Properties of Clay. Intl. J. Sci. Resrch. 4(5): 1440 - 1444.

Ratnaweera, P; Meegoda, J (2006). Shear strength and stress-strain behaviour of contaminated soils. Geotech. Testing J.. 29(2): 133-140.

Sridharan, A; El-Shafei, A; Miura, N (2002). Mechanisms Controlling the Undrained Strength Behavior of Remolded Ariake Marine Clays. Marine Geores. \& Geotech.. 20(1): 21-50.

Umesha, TS; Dinesh, SV; Sivapullaiah, PV (2012) Effects of acids on geotechnical properties of black cotton soil. Intl. J. Geology. 6(3); 69-76. 